Швецов В. Л.

Акционерное общество «Турбоатом». Украина, г. Харьков

\title{
РАЗРАБОТКА И ВНЕДРЕНИЕ КОНДЕНСАТОРОВ ПАРОВЫХ ТУРБИН АТОМНЫХ ЭЛЕКТРОСТАНЦИЙ
}

Разработка научно-технических основ создания и внедрения высокоэффективных и надежных конструкций направлена на создание конденсаторов нового поколения «блочно-модульного» исполнения с трубными системами из коррозионно-стойкого материала для турбоустановок мощностью 1000 МВТ с реакторами ВВЭР-1000 и предназначена для замены физически и морально устаревших конструкций существующих конденсаторов, которые отработали свой ресурс на атомных әлектростанциях Украины, а также для әнергоблоков АЭС при новом строительстве с учетом повышения надежности, работоспособности и увеличения срока службы конденсаторов. [dx.doi.org/10.29010/083.1]

Ключевые слова: конденсатор «блочно-модульного» исполнения; корпус; камеры; крышки; конденсатосборник; патрубок переходной; трубы охлаждающие; доски наружные; доски промежуточные; турбоустановка; блоки-модулей; прирост электрической мощности.

\section{Актуальность разработки}

Стратегия развития атомной энергетики Украины, которая обеспечивает устойчивость систем энергоснабжения на длительную перспективу и гибкость реакции на непрерывные изменения технологической и экономической обстановки, является важнейшим фактором научно-технического прогресса, состояния и развития энергетики, лежащая в основе любого производственного процесса. Bсе это способствует повышению роли атомной энергетики в энергообеспечении экономики страны. По производству электроэнергии на атомных электростанциях (АЭС) Украина входит в десятку, а по вкладу полученной электроэнергии в общем объеме электроэнергии - в пятерку стран мира. Согласно Энергетической стратегии Украины на период до 2035 г. потребление электроэнергии в Украине в 2035 должно вырасти с 163,7 (2015 г.) до 195 млрд. кВтхчас при её выработке на АЭС
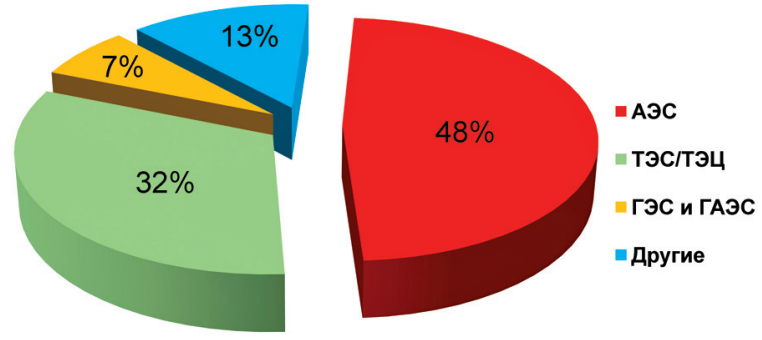

Рис. 1. Выработка электроэнергии на Украине в 2035 году в объеме 94 млрд. кВт×час, что составит около $48 \%$ от всей выработки электроэнергии на Украине (см. рис. 1).

На Украине действуют 4-е атомные электростанции с 15-ю энергоблоками:

- ОП «Запорожская АЭС» с 6-ю энергоблоками типа ВВЭР-1000 общей установленной электрической мощностью 6000 МВт, которая является крупнейшей в Европе;

- ОП «Южно-Украинская АЭС» с 3-мя энергоблоками типа ВВЭР-1000 общей установленной электрической мощностью $3000 \mathrm{MB}$;

- ОП «Ровенская АЭС» с 2-мя энергоблоками типа ВВЭР-1000 и с 2-мя энергоблоками типа ВВЭР-440 общей установленной электрической мощностью 2880 МВт;

- ОП «Хмельницкая АЭС» с 2-мя энергоблоками типа ВВЭР-1000 общей установленной электрической мощностью 2000 МВт и с 2-мя, находящимися на консервации типа ВВЭР-1000.

Данные по АЭС Украины представлены в таблице 1.

В 2018 году 10 энергоблоков АЭС выходят на срок эксплуатации 30 лет, а ещё для 2-х энергоблоков этот срок закончится в 2019 году.

Для выполнения требований по обеспечению экономики Украины электроэнергией до 2035 г. необходимо не только провести реновацию действующих АЭС с модернизацией оборудования, но и целесообразно достроить «замороженные» энергоблоки № 3 и № 4 ОП «Хмельницкая АЭС», что 


\begin{tabular}{|c|c|c|c|c|c|}
\hline Название & $\begin{array}{c}\text { № } \\
\text { блока }\end{array}$ & Тип реактора & $\begin{array}{c}\text { Установленная } \\
\text { электрическая } \\
\text { мощность, МВт }\end{array}$ & $\begin{array}{c}\text { Ввод } \\
\text { в эксплуатацию }\end{array}$ & Топливо \\
\hline \multirow{6}{*}{$\begin{array}{c}\text { ОП } \\
\ll \text { «апорожская } \\
\text { АЭС» }\end{array}$} & 1 & ВВЭР-1000 & 1000 & 1984 & ТВЭЛ \\
\hline & 2 & ВВЭР-1000 & 1000 & 1985 & ТВЭЛ \\
\hline & 3 & ВВЭР-1000 & 1000 & 1986 & ТВЭЛ \\
\hline & 4 & ВВЭР-1000 & 1000 & 1987 & ТВЭЛ \\
\hline & 5 & ВВЭР-1000 & 1000 & 1989 & ТВЭЛ и Westinghouse \\
\hline & 6 & ВВЭР-1000 & 1000 & 1995 & ТВЭЛ \\
\hline \multirow{4}{*}{$\begin{array}{c}\text { ОП } \\
\text { «Ровенская АЭС» }\end{array}$} & 1 & ВВЭР-440 & 440 & 1980 & ТВЭЛ \\
\hline & 2 & ВВЭР-440 & 440 & 1981 & ТВЭЛ \\
\hline & 3 & ВВЭР-1000 & 1000 & 1986 & ТВЭЛ \\
\hline & 4 & ВВЭР-1000 & 1000 & 2004 & ТВЭЛ \\
\hline \multirow{4}{*}{$\begin{array}{c}\text { ОП } \\
\text { «Хмельницкая } \\
\text { АЭС» }\end{array}$} & 1 & ВВЭР-1000 & 1000 & 1987 & ТВЭЛ \\
\hline & 2 & ВВЭР-1000 & 1000 & 2004 & ТВЭЛ \\
\hline & 3 & ВВЭР-1000 & 1000 & $\begin{array}{c}\text { строительство } \\
\text { заморожено }\end{array}$ & - \\
\hline & 4 & ВВЭР-1000 & 1000 & $\begin{array}{c}\text { строительство } \\
\text { заморожено }\end{array}$ & - \\
\hline \multirow{3}{*}{$\begin{array}{c}\text { ОП «Южно- } \\
\text { Украинская АЭС» }\end{array}$} & 1 & ВВЭР-1000 & 1000 & 1982 & ТВЭЛ \\
\hline & 2 & ВВЭР-1000 & 1000 & 1985 & ТВЭЛ \\
\hline & 3 & ВВЭР-1000 & 1000 & 1989 & ТВЭЛ и Westinghouse \\
\hline
\end{tabular}

позволит повысить выработку электроэнергии в Украине.

Строительство новых энергоблоков АЭС является достаточно затратным и длительным проектом. В то же время модернизация имеющихся мощностей на АЭС, будучи менее масштабным проектом, может проходить постепенно, требует меньших средств, позволяет воспользоваться имеющейся инфраструктурой и не вызывает дополнительных вопросов о целесообразности эксплуатации АЭС со стороны общественности. Значительный прирост электрической мощности на АЭС может быть достигнут модернизацией вспомогательного теплообменного оборудования турбоустановок - конденсаторов паровых турбин. В Украине такое оборудование производит предприятие $\mathrm{AO}$ «Турбоатом», что позволяет однозначно уменьшить импортную зависимость необходимых проектов по модернизации конденсаторов для АЭС. Согласно утвержденному плану по повышению надежности парогенераторов и конденсаторов турбоустановок АЭС ГП «НАЭК «Энергоатом» на период 2014 г....2020 г., ПН-Д.0.03.539-14 существующие конденсаторы турбоустановок мощностью 1000 МВт на АЭС Украины должны быть заменены на конденсаторы нового поколения в «блочномодульном» исполнении с использованием трубных систем из коррозионно-стойкого материала.

\section{Концепция разработки}

Конденсаторы паровых турбин, в значительной степени определяют экономичность работы турбоустановок АЭС большой мощности. Особенно заметно влияние ухудшения работы конденсаторов на экономичность энергоблоков АЭС, где удельные расходы пара в конденсаторах намного выше, чем на ТЭС. Нарушения в работе конденсаторов приводят к вынужденному снижению электрической мощности и экономичности турбоустановки, её 
надежности и работоспособности, а также к существенной недовыработке электроэнергии энергоблока АЭС. Моральное и физическое старение работающего теплообменного оборудования на атомных электростанциях Украины привело к значительным потерям по экономичности и резкому снижению технико-экономических показателей энергоблоков. Освоенные в настоящее время инженерные и конструктивные решения и эксплуатационный опыт работы турбоустановок мощностью 1000 МВт позволили создать конструкцию конденсаторов нового поколения для эффективного повышения экономичности энергоблоков ВВЭР-1000 с учетом существующих компоновочных решений по машинному залу. Основной причиной, определяющей необходимость модернизации конденсаторов, явилось повреждение металла трубных систем, которое вызвано эрозией-коррозией под влиянием турбулентного потока охлаждающей воды, насыщенной кислородом и содержащей твердые частицы и другие примеси, что приводит к нарушению водяной плотности трубных систем, выноса меди в цикл турбоустановки и, в конечном итоге, к потере электрической мощности турбоустановки, сокращению ресурса и ухудшению эксплуатационной надежности вспомогательного оборудования и парогенераторов, что, в конечном счете, резко ухудшает показатели работы АЭС. Кроме того, трубные системы существующих конденсаторов изготовлены из материалов содержащих медь. Это является главным источником поступления соединений меди в цикл турбоустановки и, как следствие, в парогенераторы. Медь и её окиси, которые накапливаются в элементах конструкции парогенераторов, приводят к коррозионному повреждению металла вследствие образования контактной пары в среде электролита, при этом процессы дентинга и питтинга значительно ускоряются в присутствии соединений хлорид-ионов и сульфат-ионов. Исключение из оборудования второго контура материалов, содержащих медь и полное отсутствие протечек воды в конденсаторах являются приоритетными и главными задачами для обеспечения надежной и безопасной работы оборудования турбоустановки и, в конечном итоге, приводит к улучшению показателей работы энергоблоков АЭС. Поэтому, концепция по модернизации конструкции конденсаторов определяет следующее:

- обеспечение вакуумной и водяной плотности конденсатора и требований, связанных с деаэрацией конденсата;

- обеспечение расчетного значения давления отработавшего пара турбины в процессе её эксплуатации; надежность и работоспособность во всех режимах эксплуатации;

• обеспечение заданного срока эксплуатации.

\section{Цель разработки}

Целью разработки является создание и внедрение высокоэффективных и надежных конструкций конденсаторов нового поколения «блочно-модульного» исполнения типа К-38080 и К-57530, которые превосходят зарубежные аналоги по технико-экономическим показателям и могут быть использованы при модернизации теплообменного оборудования на действующих и при строительстве новых АЭС Украины. Это достигается за счет:

• исключения медно-никелевых сплавов;

- снижения давления пара в конденсаторах по абсолютной величине;

- разработки трубного пучка «модульной» конструкции;

• обеспечения вакуумной и водяной плотности конденсаторов;

- снижения кислородной составляющей в конденсате;

- повышения поверхности теплообмена за счет применения тонкостенных сварных труб меньшего диаметра;

- применения коррозионно-стойких материалов для труб охлаждающих и досок наружных;

- применения защитных антикоррозионных покрытий внутренних поверхностей конденсаторов;

- повышение экономических показателей работы турбоустановки за счет прироста электрической мощности турбоустановки на зажимах генератора;

- разработки конструкции корпуса в виде отдельных модулей «блочно-модульного» исполнения полной заводской готовности с набранными трубами охлаждающими на предприятии-изготовителе;

- установки конденсаторов на существующие опоры стержневые фундамента без изменения его конструкции и характеристик;

- сокращения сроков межремонтного периода, сроков монтажа и увеличения срока эксплуатации.

С учетом поставленной цели и для достижения правильности разработки был решен целый ряд задач, в частности, выполнен фактический анализ работоспособности существующих конденсаторов турбоустановок мощностью 1000 МВт; выполнены комплексные исследования надежности и эффективности работающих турбоустановок и оценены влияния характеристик конденсаторов на экономичность работы паровых турбин и энергоблоков в целом; выполнен динамический анализ системы «турбина - конденсатор - фундамент». Предложенные решения в поставленных задачах на основе научных разработок позволили создать конструкцию конденсаторов нового поколения «блочно-модульного» исполнения для замены физически и морально устаревших конструкций конденсаторов на работающих АЭС, которые также однозначно могут использоваться и при строительстве новых энергоблоков АЭС Украины. 


\section{Объект разработки}

Объектом разработки и исследования являются конденсаторы бокового расположения турбоустановки К-1000-60/1500 на энергоблоке № 2 ОП «ЮжноУкраинская АЭС» и конденсаторы подвального расположения турбоустановки К-1000-60/1500-2 на энергоблоке № 3 ОП «Запорожская АЭС» с реакторами ВВЭР-1000 (см. рис. 2).

\section{Предмет и методы разработки}

Предметом разработки и исследования явилась оптимизация новой конструкции конденсаторов «блочно-модульного» исполнения с трубными системами из коррозионно-стойких материалов, включая, «модульную» компоновку трубного пучка. В ходе разработки и исследования были применены методы математического моделирования, решения прямых задач математической физики и сопряженных задач теплообмена, методы современной прикладной термодинамики и техникоэкономической оптимизации.

\section{Научная новизна разработки}

Научная новизна разработки и исследования заключаются в следующем:

- на базе современных методов прикладной термодинамики создана методология системно-структурного анализа для решения задач повышения качества инженерных решений по совершенствованию оборудования энергетических установок и проведению их термоэкономической оптимизации;

- впервые создана комплексная методология расчета теплогидравлических характеристик конденсаторов нового поколения «блочно-модульного» исполнения с учетом требований обеспечения вибрационной прочности и надежности, конструк- тивной прочности и экономичности работы оборудования турбоустановки при сохранении его массогабаритных характеристик и строительных конструкций машинного зала энергоблоков.

\section{Практическая значимость}

Разработана конструкция отдельных модулей полной заводской готовности с набранными охлаждающими трубами, что позволило спроектировать конденсаторы нового поколения в «блочно-модульном» исполнении, которая обеспечивает высокие технико-экономические показатели в широком диапазоне режимов работы с последующим приростом электрической мощности турбоустановки на зажимах генератора за счет углубления расчетного давления пара.

В конструкциях конденсаторов применены трубы охлаждающие и доски наружные из коррозионно-стойких материалов, что обеспечивает плотность трубных систем, повышает надежность, работоспособность, безопасность и увеличивает срок службы.

\section{Научно-технические результаты}

Созданная конструкция конденсаторов нового поколения «блочно-модульного» исполнения для турбоустановок мощностью 1000 МВт, отвечает современным требованиям по эффективности и надежности, как для модернизации действующих АЭС, так и для строительства новых. Используемый научно-технический подход в области современной прикладной термодинамики и теплотехники при оптимизации конструктивных элементов конденсаторов, а также опыт проектирования и эксплуатации конденсаторов, была отработана методика и создана уникальная конструкция конденсаторов «блочно-модульного» исполнения, которые
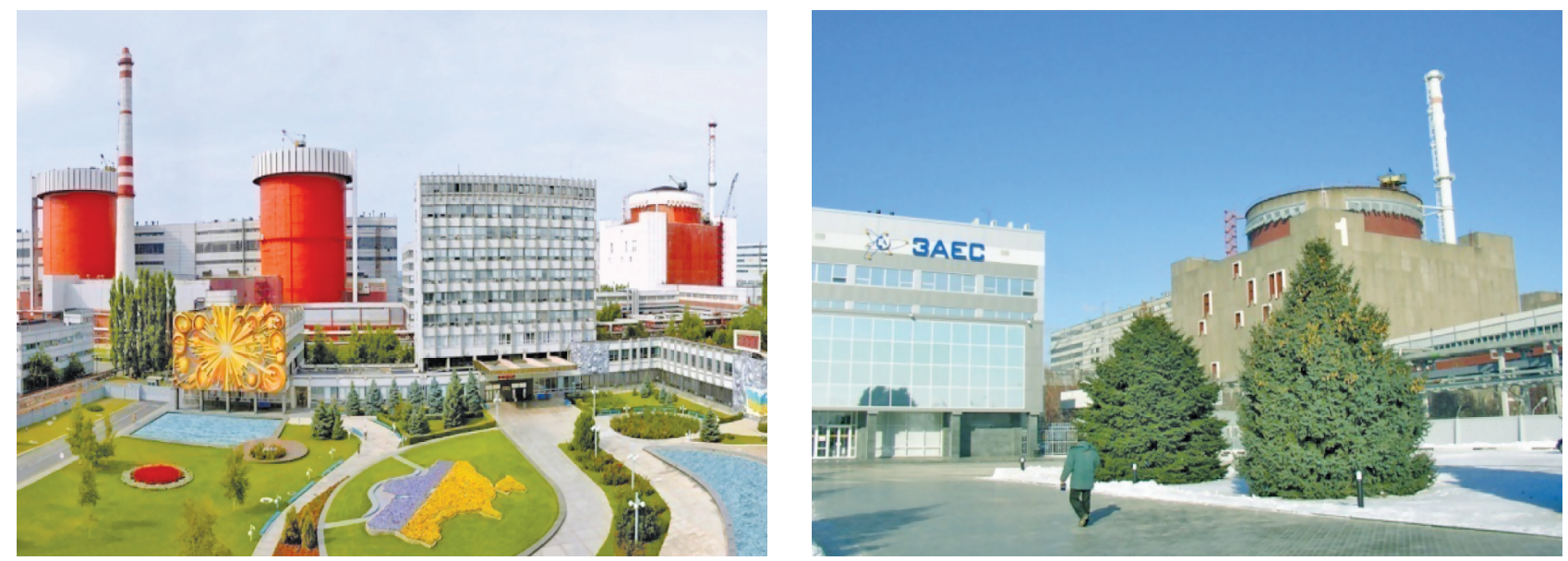

Рис. 2. ОП «Южно-Украинская АЭС» и ОП «Запорожская АЭС» 
могут работать в различных климатических условиях и при различных условиях эксплуатации энергоблоков АЭС мощностью 1000 МВт, включая повышение тепловой мощности реакторной установки энергоблоков до 107\%. На базе современных методов прикладной термодинамики создана методология системно-структурного анализа для решения задач повышения качества инженерных решений по совершенствованию оборудования турбоустановок. Предложенная методология позволила оценить влияние на эффективность турбоустановки всех основных элементов, найти распределение и характер составляющих потерь в турбоустановке, определить относительное влияние каждого элемента в системе, установить характеристику связей между потерями в элементах. Изложенный в рамках методологии подход дает возможность рассмот- реть все изменения, происходящие в работе конденсаторов и других элементов оборудования с момента введения в систему и до получения конечного продукта с учетом цены каждого внутреннего потока. Это позволило определить стоимость энергетических потерь для заданной структуры технологической схемы турбоустановки и выполнить её оптимизацию по модернизации, по результатам которой определены геометрические параметры узлов конденсаторов.

\section{Опыт разработки}

Конструкция конденсаторов разработана на основе опыта проектирования, изготовления и поставок конденсаторов турбин паровых мощностью 220 ... 1100 МВт для АЭС, представленных в таблице 2.

Таблица 2

\begin{tabular}{|c|c|c|}
\hline Наименование & Объект & Примечание \\
\hline \multicolumn{3}{|c|}{ Поставка конденсаторов на зарубежные АЭС: } \\
\hline $\begin{array}{l}\text { Конденсаторы: } \\
\text { К-20280 и К-24040 } \\
\text { т.у. К-240-4,0 }\end{array}$ & $\begin{array}{c}\text { Индия: } \\
\text { АЭС «Кайга», блоки № } 3 \text { и № } 4 \\
\text { АЭС «РАПП», блоки № } 5 \text { и № } 6\end{array}$ & $\begin{array}{c}\text { Материал труб - сталь марки TP 316L ASTM } \\
\text { (цельная). Количество конденсаторов - } 4 . \\
\text { Поставка - } 2003 \text { г. и } 2006 \text { г. }\end{array}$ \\
\hline $\begin{array}{c}\text { Конденсатор К-33177 } \\
\text { т.у. К-1100-60/1500-2M }\end{array}$ & $\begin{array}{c}\text { «Ростовская АЭС», } \\
\text { блоки № } 3 \text { и № } 4\end{array}$ & $\begin{array}{c}\text { Материал труб - титан марки ВТ1-0 } \\
\text { (сварная) по ТУ. Количество конденса- } \\
\text { торов - 6. Поставка - } 2011 \text { г. и } 2013 \text { г. }\end{array}$ \\
\hline $\begin{array}{l}\text { Конденсатор К-38080 } \\
\text { т.у. К-1000-60/1500-2 }\end{array}$ & $\begin{array}{l}\text { «Балаковская АЭС», } \\
\text { блоки №№ 1, 2, 3, } 4\end{array}$ & $\begin{array}{c}\text { Материал труб - сталь марки TP 316L ASTM } \\
\text { (сварная) и титан марки ВТ1-0 (сварная) } \\
\text { по ТУ. Количество конденсаторов - } 12 . \\
\text { Поставка - } 2011 \text { г....2014 г. }\end{array}$ \\
\hline $\begin{array}{c}\text { Конденсатор К-49210 } \\
\text { т.у. К-1000-60/1500 }\end{array}$ & $\begin{array}{c}\text { «Калининская АЭС», } \\
\text { блоки № } 1 \text { и № } 2\end{array}$ & $\begin{array}{c}\text { Материал труб - сталь марки TP 316L ASTM } \\
\text { (сварная) Количество конденсаторов - } 4 . \\
\text { Поставка - } 2010 \text { г. и } 2012 \text { г. }\end{array}$ \\
\hline $\begin{array}{c}\text { Конденсатор К-26150 } \\
\text { т.у. К-500-60/1500 }\end{array}$ & $\begin{array}{l}\text { «Нововоронежская АЭС», } \\
\text { блок № } 5 \text { (ТА-13, ТА-14) }\end{array}$ & $\begin{array}{c}\text { Материал труб - сталь марки TP 316L ASTM } \\
\text { (сварная). Количество конденсаторов }-4 . \\
\text { Поставка - } 2012 \text { г....2013 г. }\end{array}$ \\
\hline \multicolumn{3}{|c|}{ Поставка конденсаторов на АЭС Украины: } \\
\hline $\begin{array}{c}\text { Конденсатор К-57530 } \\
\text { т.у. К-1000-60/1500 }\end{array}$ & $\begin{array}{l}\text { ОП «Южно-Украинская } \\
\text { АЭС», блоки № } 1 \text { и № } 2\end{array}$ & $\begin{array}{c}\text { Материал труб - сталь марки TP 316L ASTM } \\
\text { (сварная). Количество конденсаторов - } 4 . \\
\text { Поставка }-2016 \text { г....2017 г. }\end{array}$ \\
\hline $\begin{array}{l}\text { Конденсатор К-38080 } \\
\text { т.у. К-1000-60/1500-2 }\end{array}$ & $\begin{array}{c}\text { ОП «Запорожская АЭС», } \\
\text { блоки № } 3 \text { и № } 4\end{array}$ & $\begin{array}{c}\text { Материал труб - сталь марки TP 316L ASTM } \\
\text { (сварная). Количество конденсаторов - } 6 . \\
\text { Поставка }-2017 \text { г....2018 г. }\end{array}$ \\
\hline $\begin{array}{c}\text { Конденсатор К-25170 } \\
\text { т.у. К-1000-60/3000 }\end{array}$ & $\begin{array}{c}\text { ОП «Южно-Украинская } \\
\text { АЭС», блок № } 3\end{array}$ & $\begin{array}{c}\text { Материал труб - сталь марки TP 316L ASTM } \\
\text { (сварная). Количество конденсаторов - } 4 . \\
\text { Планируемая поставка - } 2019 \text { г. }\end{array}$ \\
\hline
\end{tabular}


Основные этапы разработки конструкции

1-й этап разработки - выбор коррозионностойких материалов для трубных систем

Материалы для трубных систем выбраны исходя из химического состава циркуляционной воды пруда-охладителя, состава возможных отложений в трубных системах, длительного срока службы и относятся к материалам с повышенной прочностью, обладают высокой коррозионной стойкостью, соответствуют современным требованиям, предъявляемым к конструктивным материалам для оборудования АЭС. Кроме того, при выборе материалов и конструктивных размеров элементов трубных систем по условиям статической и циклической прочности учитывалась величина коррозионного износа за срок эксплуатации 30 лет. Для трубных систем конденсаторов применены следующие материалы: трубы охлаждающие - сталь марки TP 316L ASTM A249/A249M-10а; доски наружные сталь марки 316L ASTM A240/A240M-15b; доски промежуточные - сталь марки 09Г2С ДСТУ-8541; остальные детали - сталь марки Сталь20 ГОСТ 1577.

2-й этап разработки - оптимизация поверхности теплообмена

Расположение нового трубного пучка выполнялось на фиксированной торцевой площади доски наружной для конденсаторов с помощью труб различного диаметра $23 . . .28$ мм и толщиной $0,5 \ldots$ 0,7 мм, с учетом расчетных проходных сечений по скоростям в проходах между трубными пучками для оптимизации теплоотдачи и расчетных характеристик конденсаторов. С учетом выполненной оптимизации в новых конструкциях трубных систем применены трубы охлаждающие сортамента: $\varnothing 23 \times 0,5$ мм и $\varnothing 23 \times 1,0$ мм, образующие оптимальный трубный пучок - поверхность теплообмена, что позволило на фиксированной торцевой площади трубных досок оптимизировать и увеличить поверхность теплообмена: для конструкции с подвальным расположением конденсаторов - с 33160 м $^{2}$ до 38080 м $^{2}$ и для конструкции с боковым расположением конденсаторов - с $45600 \mathrm{~m}^{2}$ до $57530 \mathrm{~m}^{2}$, а также повысить эффективность работы конденсаторов за счет снижения давления пара (вакуума) в конденсаторах, что в конечном итоге привело к расчетному приросту электрической мощности турбоустановки на зажимах генератора. Разработанная компоновка трубного пучка «модульного» типа конденсаторов ранее не применялось в конструкциях существующих конденсаторов, не имеет аналогов в мировой практике проектирования. Новая «модульная» компоновка трубного пучка, с учетом требований по сварке модулей между собой на монтаже, имеет оптимальную тепловую эффективность и оптимальные габариты по поверхности теплообмена и представлена на рисунке 3.

3-й этап разработки - оптимизация количества модулей в трубных системах (в корпусах) конденсаторов

Критериями выбора оптимального количества модулей в корпусах конденсаторов являются:

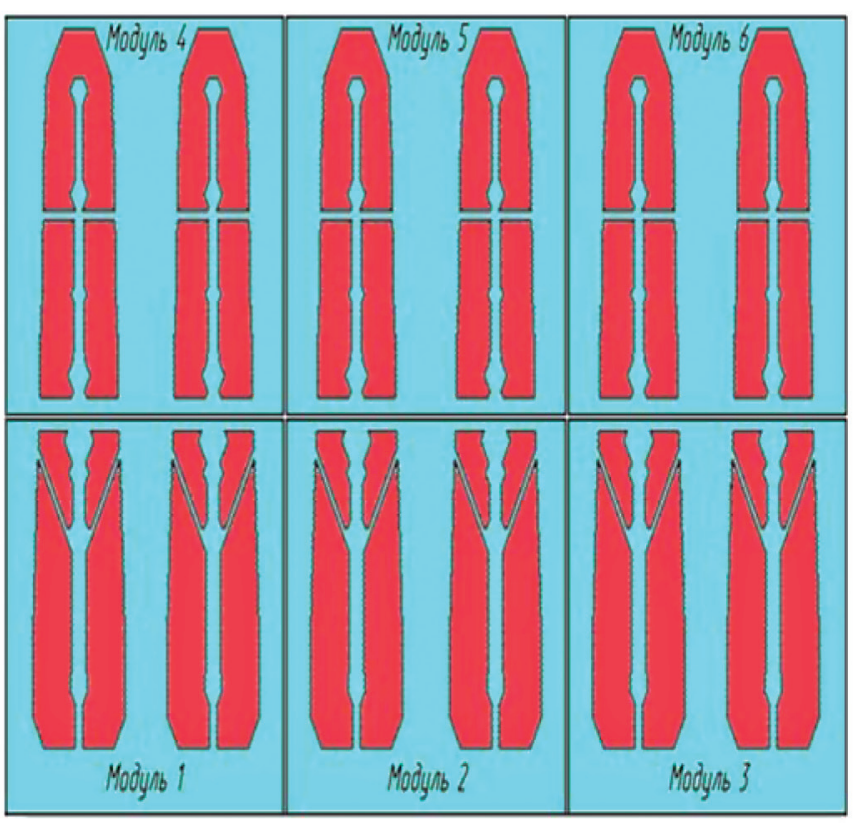

Конденсатор К-38080

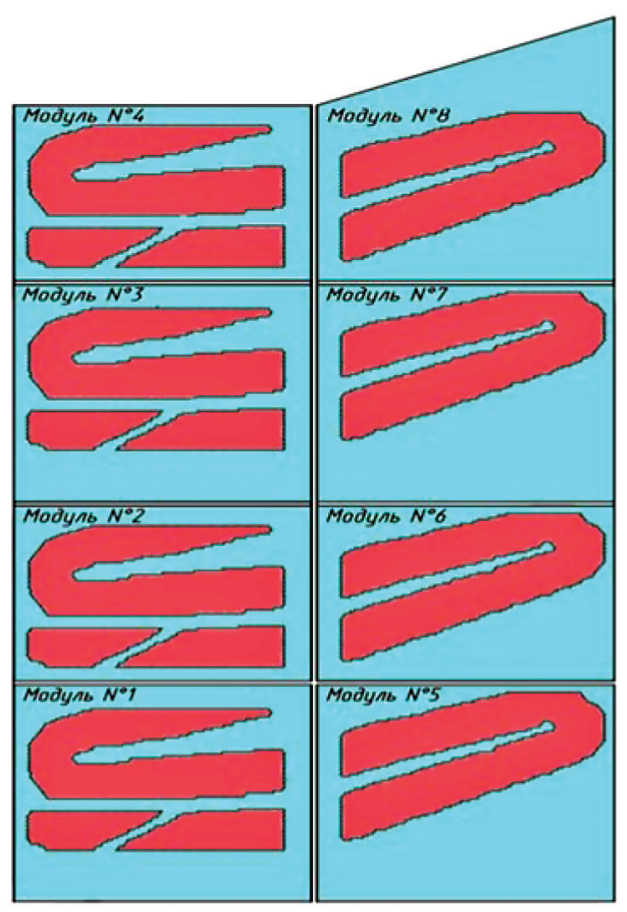

Конденсатор К-57530

Рис. 3. «Модульные» компоновки трубного пучка 


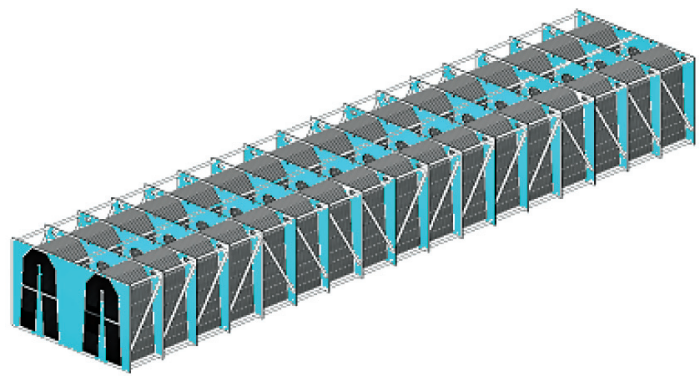

Модуль №№ 4, 5, 6 верхней части корпуса

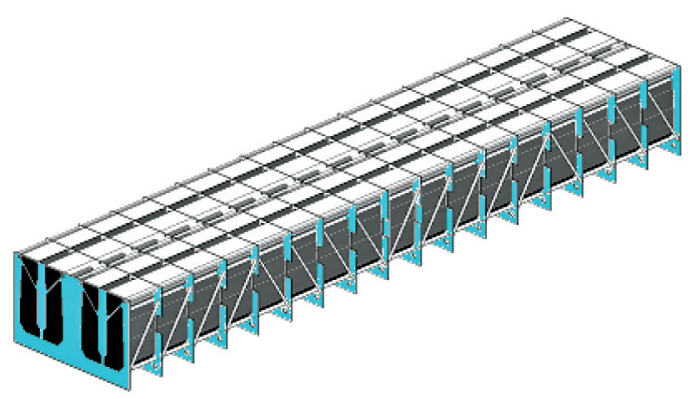

Модуль №№ 1, 2, 3 нижней части корпуса

Рис. 4. Модули корпуса конденсатора К-38080 т.у. К-1000-60/1500-2

- геометрические размеры торцевой площади трубных досок;

- суммарная поверхность теплообмена;

- количество труб охлаждающих;

- конфигурация трубного пучка с учетом кратности охлаждения;

- расчетные скорости в проходных сечениях в трубном пучке;

- места воздухоудаления и сброса высокопотенциальных потоков пара;

- устойчивость конструкции;

- места установки на опоры стержневые фундамента.

Все это в комплексе определило выбор количества модулей в корпусах рассматриваемых конденсаторов.

С учетом оптимизированной поверхности теплообмена во 2-м этапе конструктивно принято количество модулей: для конденсатора т.у. К-100060/1500-2 - 6-ть модулей для каждого корпуса и для конденсатора т.у. К-1000-60/1500 - 8-мь модулей для каждого корпуса (см. рис. 4 и 5). Применение компоновки трубного пучка «модульного» типа позволило спроектировать и изготовить «блоки-модули» полной заводской готовности, их свободную транспортировку и удобство выполнения монтажных работ на АЭС.

4-й әтап разработки - оптимизачия количества досок промежуточных, их толщины и расстояния между ними с учетом вибрачионной прочности и устойчивости труб охлаждающих

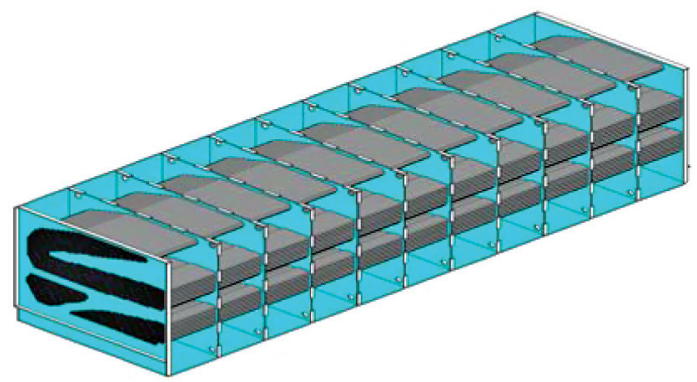

Модуль корпуса №№ 1, 2, 3, 4
При обтекании труб охлаждающих паровым потоком в конденсаторе рассматриваются два вида формирования возможной неустойчивости труб охлаждающих: механическая вибрация, которая эквивалентна частоте вращения ротора 25 Гц, передаваемая через корпусные элементы ЦНД и газодинамическая вибрация, связанная с обтеканием паровым потоком труб охлаждающих. Для исключения повреждения труб охлаждающих от воздействия механических и аэродинамических возбуждающих сил, с учетом прочности и устойчивости, оптимизировано конструктивное расстояние между промежуточными и наружными досками на базе расчетов вибрационной прочности. Из условия вибрационной прочности труб охлаждающих и устойчивости всей конструкции корпусов конденсаторов данное мероприятие привело к технической необходимости увеличения количества промежуточных досок в новых конденсаторах по сравнению с существующим количеством промежуточных досок в работающих конденсаторах. Изменение количества промежуточных досок влияет на вибрационную отстройку и запас по прочности, а толщина - на массовые характеристики и нагрузки, передаваемые на опоры стержневые фундамента, при этом, было учтено, что увеличенное количество и уменьшение толщин промежуточных досок не изменит массовых нагрузок на существующие опоры стержневые и характеристики фундамента. Для модулей конденсатора т.у. К-1000-60/1500-2 принято: 2 доски наружные и 16 досок промежуточ-

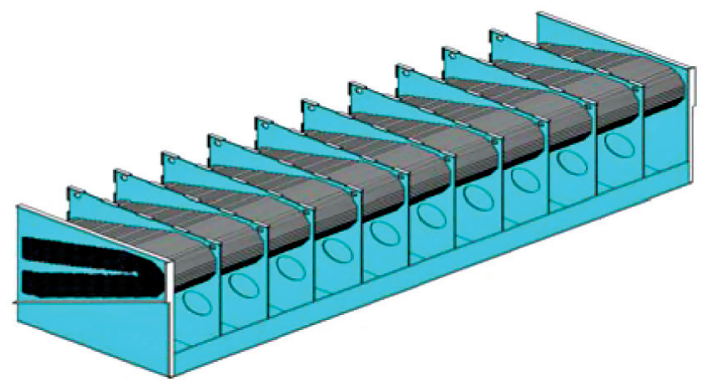

Модуль корпуса №№ 5, 6, 7, 8

Рис. 5. Модули корпуса конденсатора К-57530 т.у. К-1000-60/1500 
ных в каждом модуле, для модулей конденсатора т.у. К-1000-60/1500 принято: 2 доски наружные и 10 досок промежуточных в каждом модуле. Кроме того, установка труб охлаждающих в модулях конденсаторов по типу «лук» (см. рис. 5 и 6) обеспечивает дополнительную жесткость в соединении «труба доска наружная». Установка труб охлаждающих по типу «лук» выполнена впервые по технологии предприятия-изготовителя, является технической новизной такой конструкции и технологии, и не применялась ранее в аналогичных конструкциях конденсаторов АЭС. Установка труб охлаждающих таким способом позволяет снизить термические напряжения в местах соединения «труба - доска наружная», а также снизить в элементах конденсатора температурные и компенсационные напряжения за счет оптимального соотношения жесткостных характеристик соединенных элементов конструкции и исключает стояночную коррозию в трубах охлаждающих при неработающем конденсаторе.

5-й этап разработки - оптимизачия массовых нагрузок на существуюшие опоры стержневые фундамента

Данный этап разработки является уникальным, ранее не применялся в конструкциях работающих конденсаторов на украинских АЭС, не имеет аналогов в зарубежных конструкциях конденсаторов
АЭС, является научной и технической новизной при разработке конструктивных элементов в конденсаторах, позволяющей не только усовершенствовать конструкцию, но и выполнить основные требования Заказчика при разработке: установить конденсаторы нового поколения на существующие опоры стержневые фундамента без изменения конструкции и характеристик фундамента, с сохранением всех компоновочных решений по машинному залу (см. рис. 7).

\section{Описание конструкции}

Конденсатор «блочно-модульного» исполнения К-38080 подвального расположения

Конденсационная установка состоит их 3-х конденсаторов подвального расположения (см. рис. 9) в машинном зале турбоустановки, входящих в состав турбины паровой К-1000-60/1500-2 (ЦВД+ +3 ЦНД) и являющихся её неотъемлемой частью. Каждый конденсатор устанавливается под каждым цилиндром низкого давления (ЦНД-1, 2, 3) турбины паровой (см. рис. 8).

Конструктивно каждый конденсатор состоит из корпуса (поз. 3), камеры передней (поз. 5), камеры задней (поз. 4), крышек передних (поз. 8), патрубка переходного (поз. 1) с устройствами приёмносбросными дроссельного типа (поз. 2), конденсато-

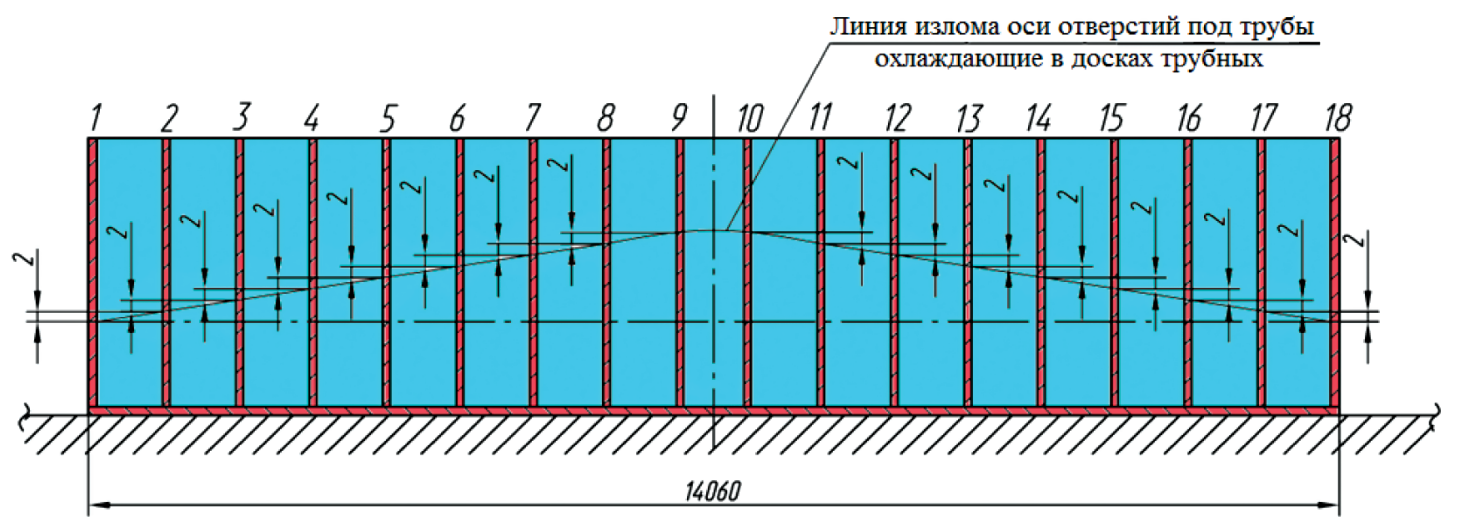

Рис. 6. Установка труб охлаждающих в модулях конденсатора К-38080

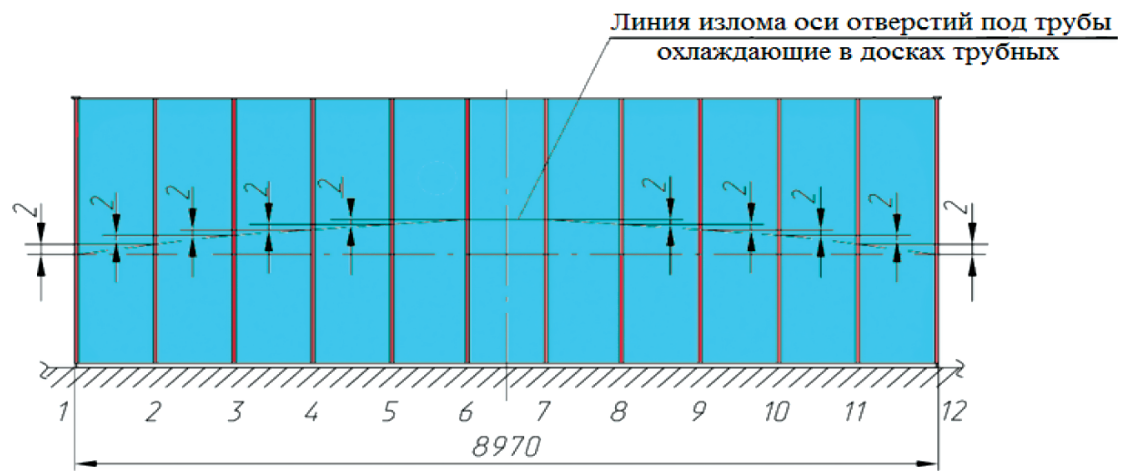

Рис. 7. Установка труб охлаждающих в модулях конденсатора К-57530 


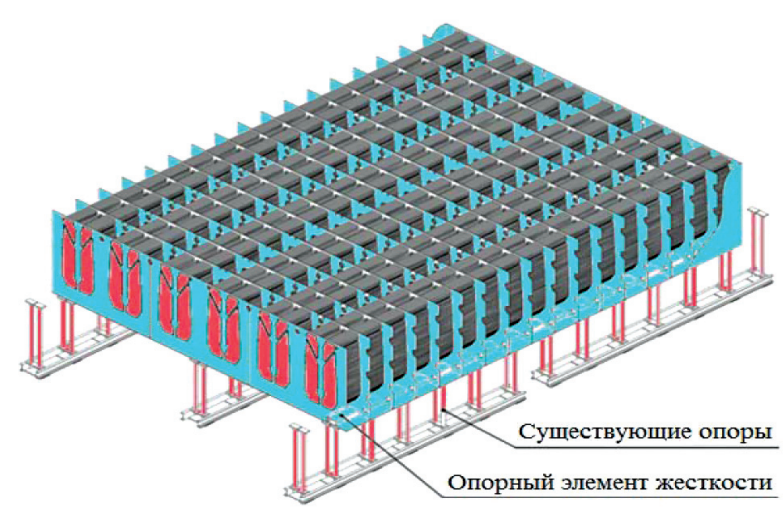

Конденсатор К-38080

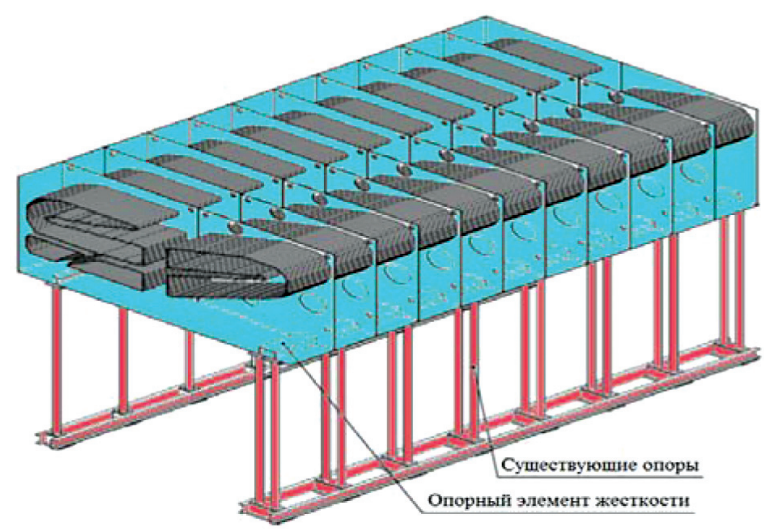

Конденсатор К-57530

Рис. 8. Установка конденсаторов на существующие опоры стержневые фундамента

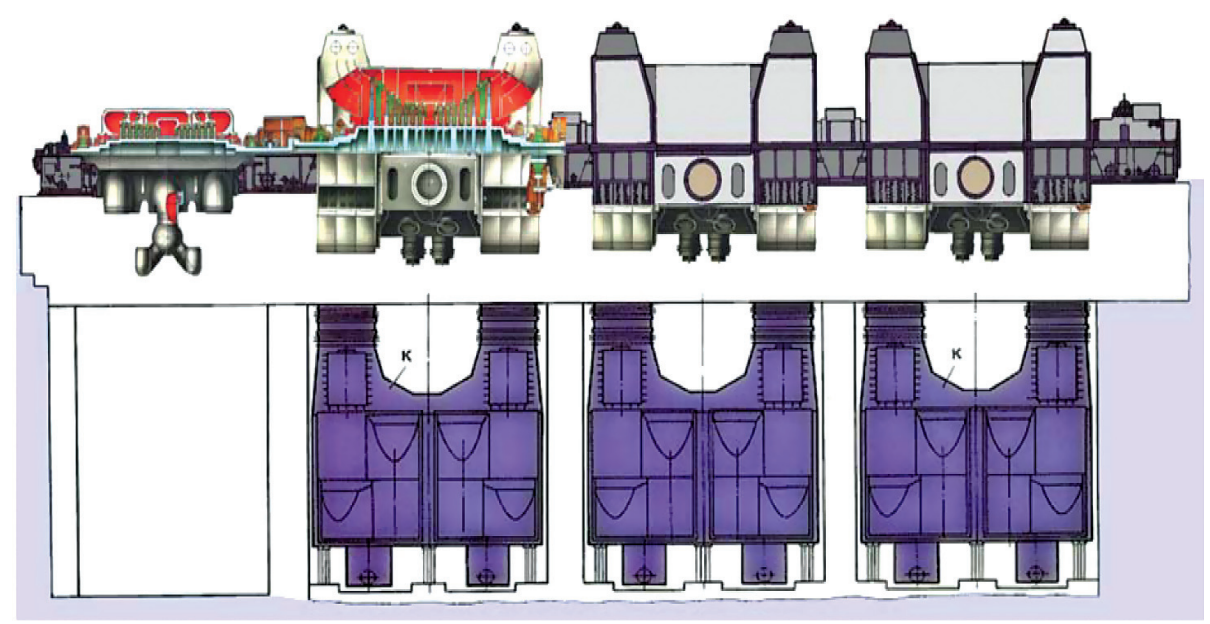

Рис. 9. Турбина паровая К-1000-60/1500-2 с конденсаторами «блочно-модульного» исполнения К-38080

сборников (поз. 6) и посредством патрубка переходного соединяется с патрубком выхлопным цилиндра низкого давления (ЦНД) турбины паровой через переходы с линзовыми компенсаторами, устанавливается на существующие опоры стержневые (поз. 7), являющиеся составной частью нижней части фундамента и воспринимающие вес конденсатора в рабочем состоянии. Корпус (поз.3) конденсатора «блочно-модульного» исполнения, состоит из 6-ти модулей (см. рис. 4), поставляемых в виде продольных «блоков-модулей» с трубами охлаждающими и соединяемых между собой на монтаже с помощью сварки.

Конденсатор «блочно-модульного» исполнения К-57530 бокового расположения

Конденсационная установка, состоит их 2-х конденсаторов бокового расположения (см. рис. 11) в машинном зале турбоустановки, входящие в состав турбины паровой К-1000-60/1500 (ЦВД+ + ЦСД+ЗЦНД) и являющихся неотъемлемой её частью. Каждый корпус конденсатора устанавливается сбоку (по ряду «А» и по ряду «Б») от каждого цилиндра низкого давления (ЦНД-1, 2, 3) турбины паровой (см. рис. 10).

Конструктивно каждый конденсатор состоит из 3 -х корпусов (поз. 1, 2, 3), камеры входной (поз. 4), камеры промежуточной (поз. 6), камеры выходной (поз. 5), крышек входных (поз. 13, 14), крышек выходных (поз. 15, 16), патрубка переходного (поз. 7, 8,9) с устройствами приёмно-сбросными дроссельного типа (поз. 17), конденсатосборников (поз. 10,11, 12) и посредством патрубка переходного (поз. $7,8,9)$ соединяется с патрубком выхлопным цилиндров низкого давления (ЦНД) турбины паровой через переходы с линзовыми компенсаторами, устанавливается на существующие опоры стержневые, являющиеся составной частью нижней части фундамента, воспринимающие вес конденсаторов в рабочем состоянии. Корпус $($ поз. $1,2,3)$ каждого конденсатора «блочно-модульного» исполнения по ряду «А» и ряду «Б» состоит из 8-ти модулей (см. рис. 5), поставляемых в виде продольных «блоков-модулей» с трубами охлаждающими и соединяемых между собой на монтаже с помощью сварки. 


\section{технологическиет 2/2018}
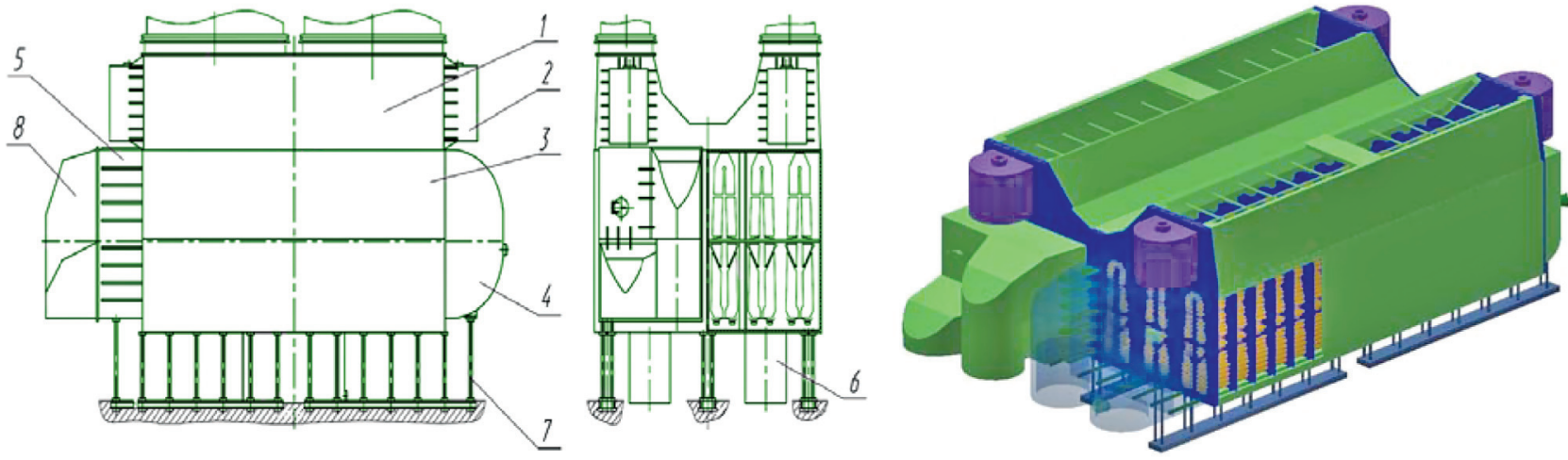

Рис. 10. Конденсатор К-38080 «блочно-модульного» исполнения

Таблица 3

Характеристика конденсатора К-38080

\begin{tabular}{|c|c|c|}
\hline № п/п п & Характеристики & Величина \\
\hline 1 & Поверхность охлаждения, м² & 38080 \\
\hline 2 & Компоновка трубного пучка & «модульная» \\
\hline 3 & Тип трубы & сварная \\
\hline 4 & Сортамент труб охлаждающих, мм & $23 \times 0,5 \times 14060 / 23 \times 1,0 \times 14060$ \\
\hline 5 & Количество труб охлаждающих, шт. & 37644 \\
\hline 6 & Крепление труб охлаждающих в досках наружных & вальцовка и сварка \\
\hline 7 & Расход пара в конденсатор, т/ч & 1114,22 \\
\hline 8 & Расчетное давление пара, кгс/см² & 0,0364 \\
\hline 9 & Расход охлаждающей воды, т/ч & 56600 \\
\hline 10 & Расчетная температура, ${ }^{\circ} \mathrm{C}$ & 15 \\
\hline 11 & Масса конденсатора, без опор, кг & 523000 \\
\hline
\end{tabular}

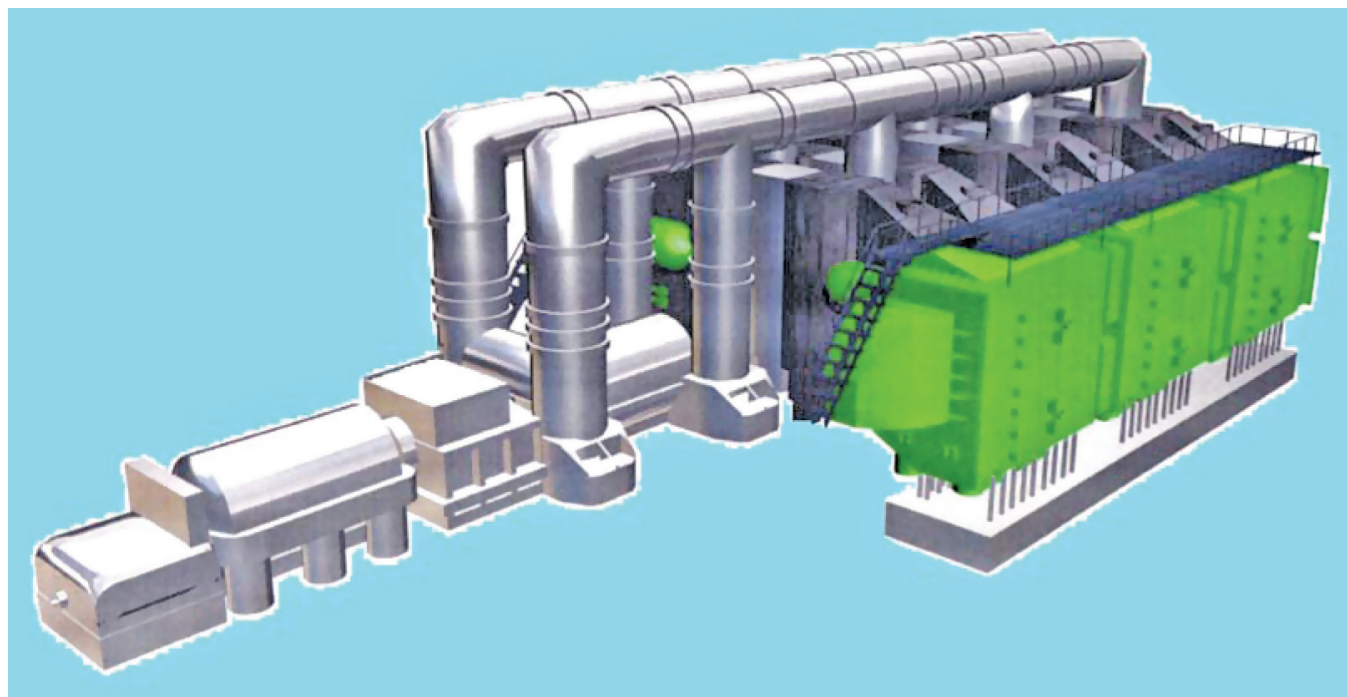

Рис. 11. Турбина паровая К-1000-60/1500 с конденсаторами «блочно-модульного» исполнения К-57530 


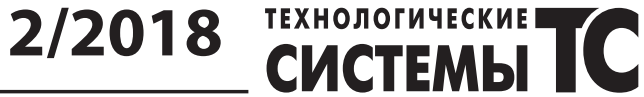

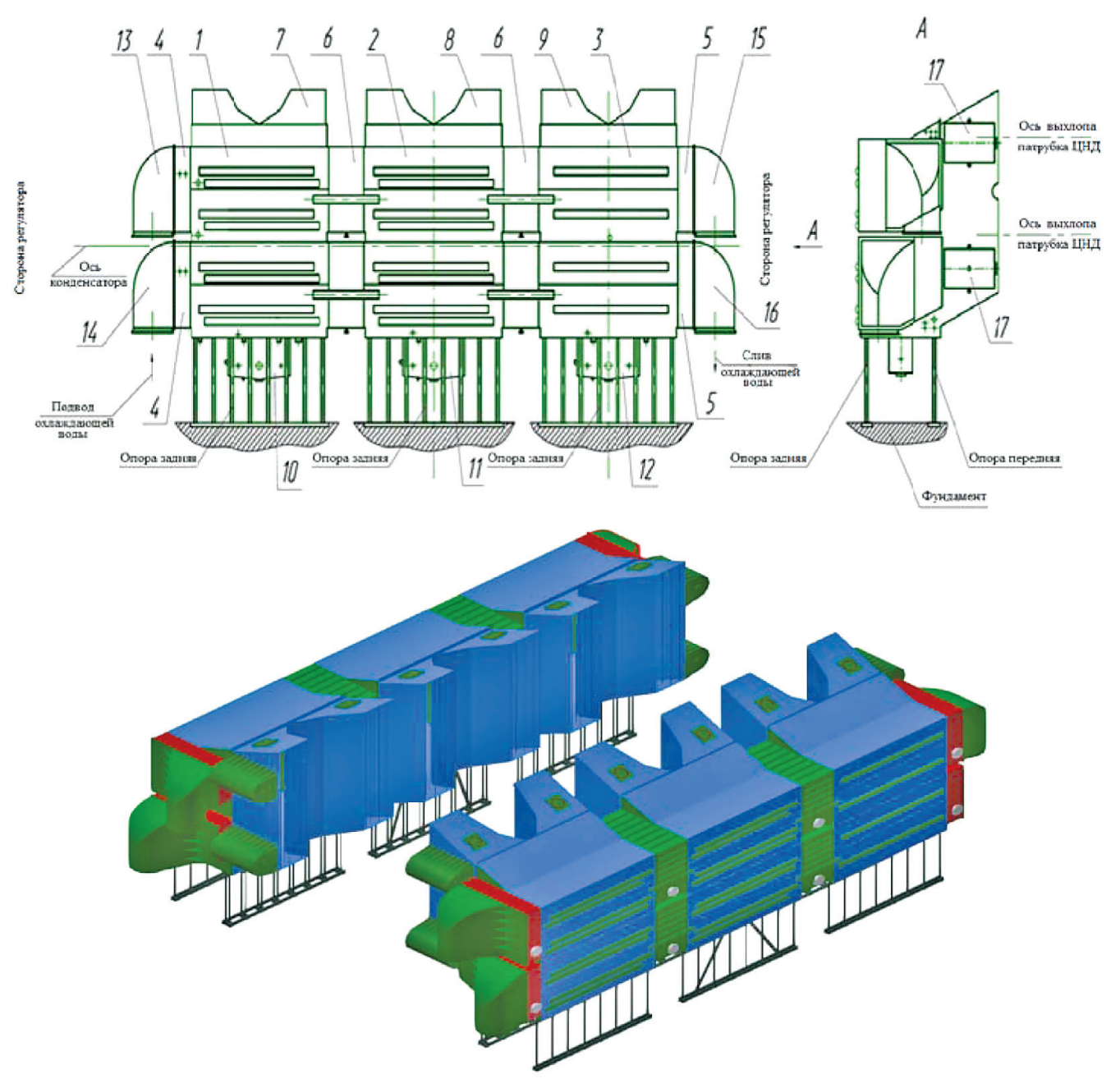

Рис. 12. Конденсаторы К-57530 «блочно-модульного» исполнения

Характеристика конденсатора К-57530

\begin{tabular}{|c|c|c|}
\hline № п/п & Характеристики & Величина \\
\hline 1 & Поверхность охлаждения, ${ }^{2}$ & 57530 \\
\hline 2 & Компоновка трубного пучка & «модульная» \\
\hline 3 & Тип трубы & сварная \\
\hline 4 & Сортамент труб охлаждающих, мм & $23 \times 0,5 \times 9000 / 23 \times 1,0 \times 9000$ \\
\hline 5 & Количество труб охлаждающих, шт. & $3 \times 29788$ \\
\hline 6 & Крепление труб охлаждающих в досках наружных & вальцовка и сварка \\
\hline 7 & Расход пара в конденсатор, т $/$ ч & $3 \times 562,0$ \\
\hline 8 & Расчетное давление пара (среднее), кгс $/$ см $^{2}$ & 0,0356 \\
\hline 9 & Расход охлаждающей воды, т $/$ ч & $3 \times 79960$ \\
\hline 10 & Расчетная температура, ${ }^{\circ} \mathrm{C}$ & 15 \\
\hline 11 & Масса конденсатора, без опор, кг & 917000 \\
\hline
\end{tabular}




\section{זехнологическиE TC 2/2018}

\section{Технология изготовления}

Технологичность конструкции узлов конденсатора при изготовлении и монтаже подтверждается технологией изготовления (см. рис. 12), а геометри-

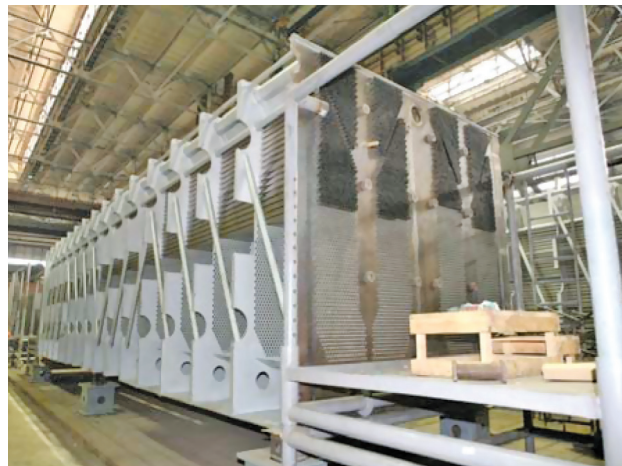

Установка труб в модуле

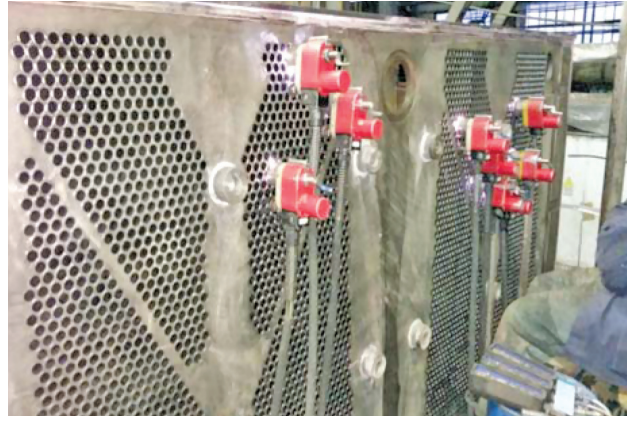

Сварочные аппараты

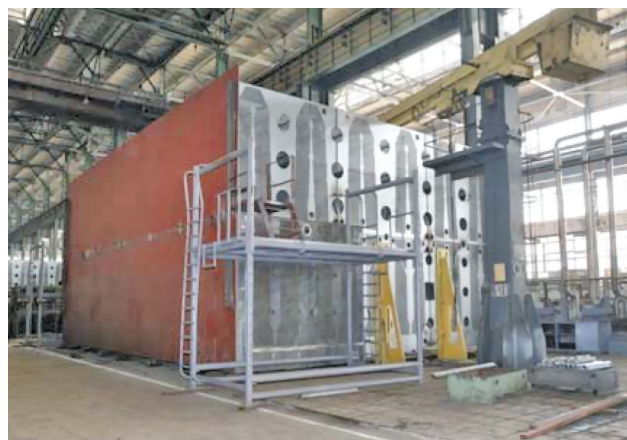

Сборка корпуса

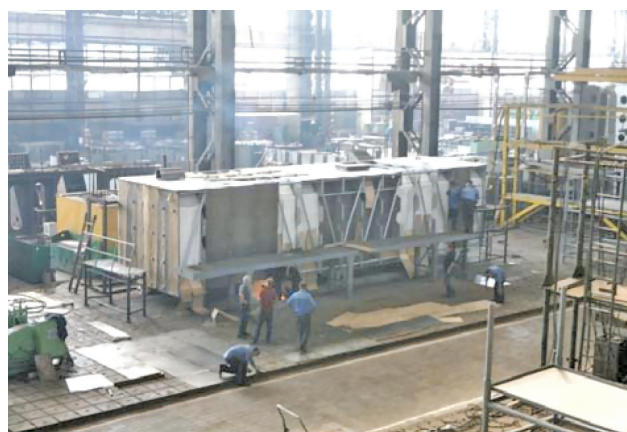

Упаковка модуля ческая совместимость модулей конденсаторов друг с другом при изготовлении и монтаже обеспечивается поэтапной контрольной сборкой модулей без и с трубами охлаждающими на предприятии.

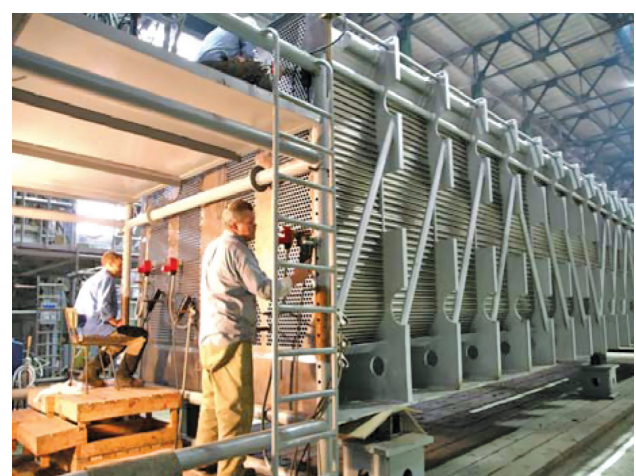

Сварка труб в доске наружной

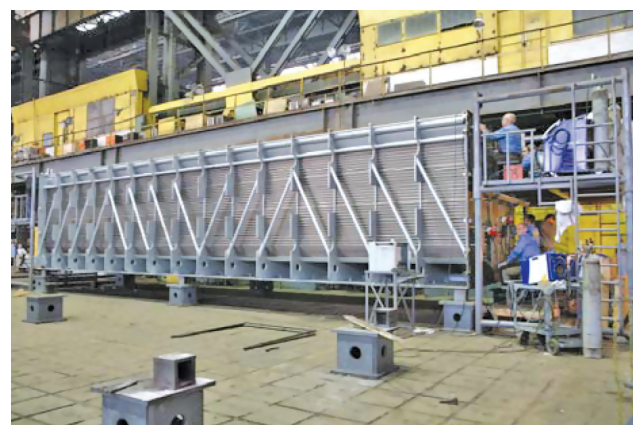

Сварка и контроль

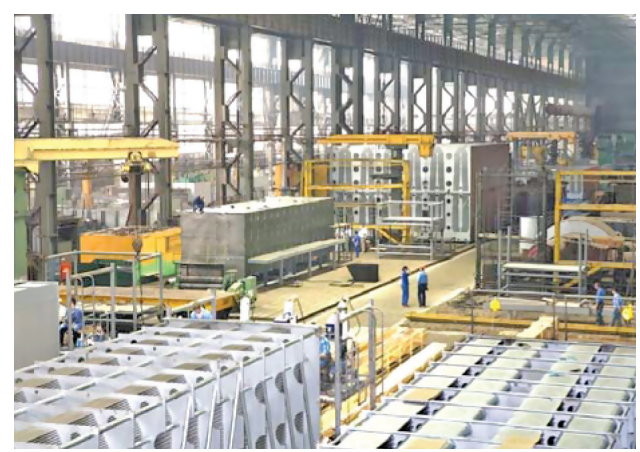

Сборка модулей

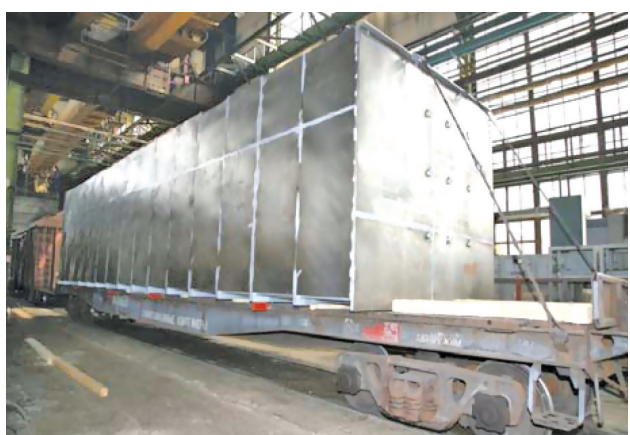

Транспортировка модуля

Рис. 13. Изготовление конденсаторов 


\section{2/2018 ПехнологическиЕТ TC}

\section{Технология монтажа}

Разработанная технология монтажа является уникальной, ранее не применялась при монтаже конденсаторов на АЭС Украины и за рубежом и не имеет аналогов при выполнении монтажных работ. Монтаж конденсаторов представлен на рисунках 13 и 14 соответственно.
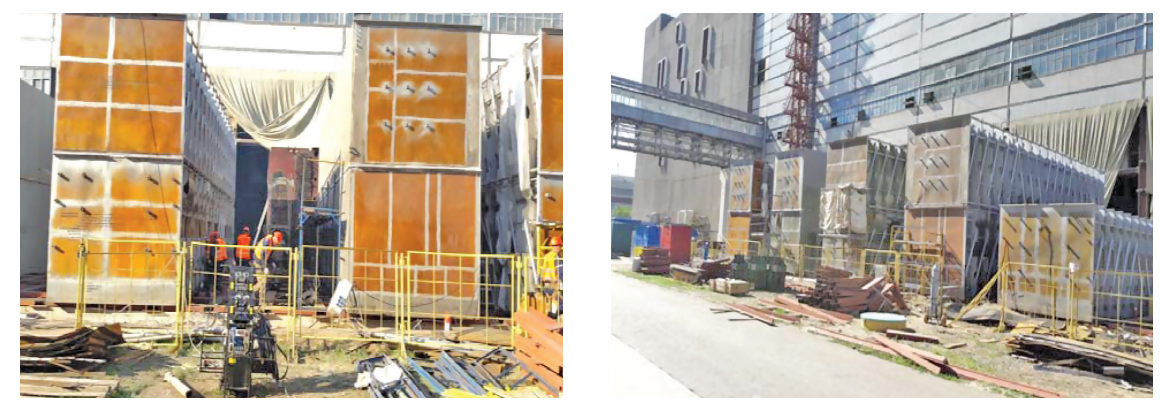

Укрупнение модулей

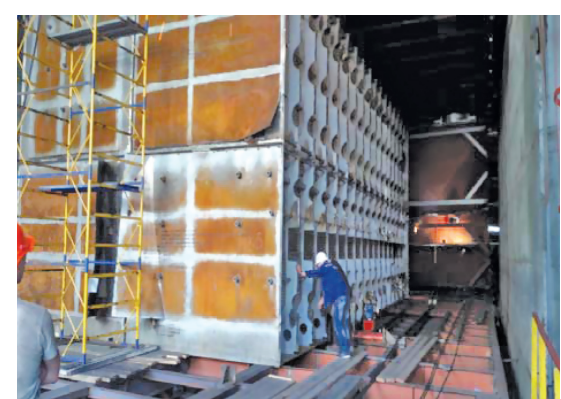

Установка

модулей

в машинном

зале

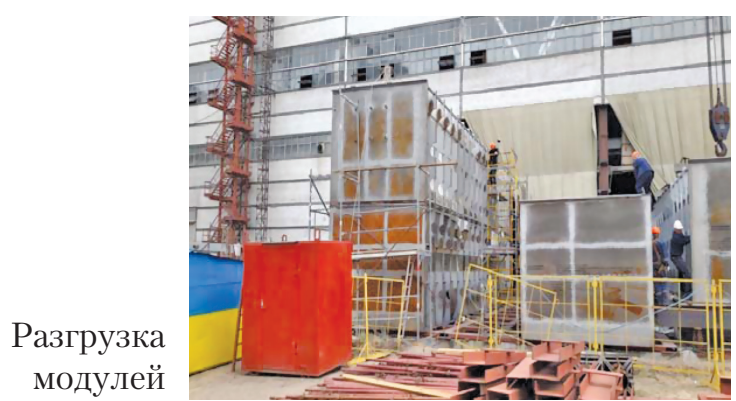

Рис. 14. Монтаж конденсатора К-38080 на ОП «Запорожская АЭС», блок № 3
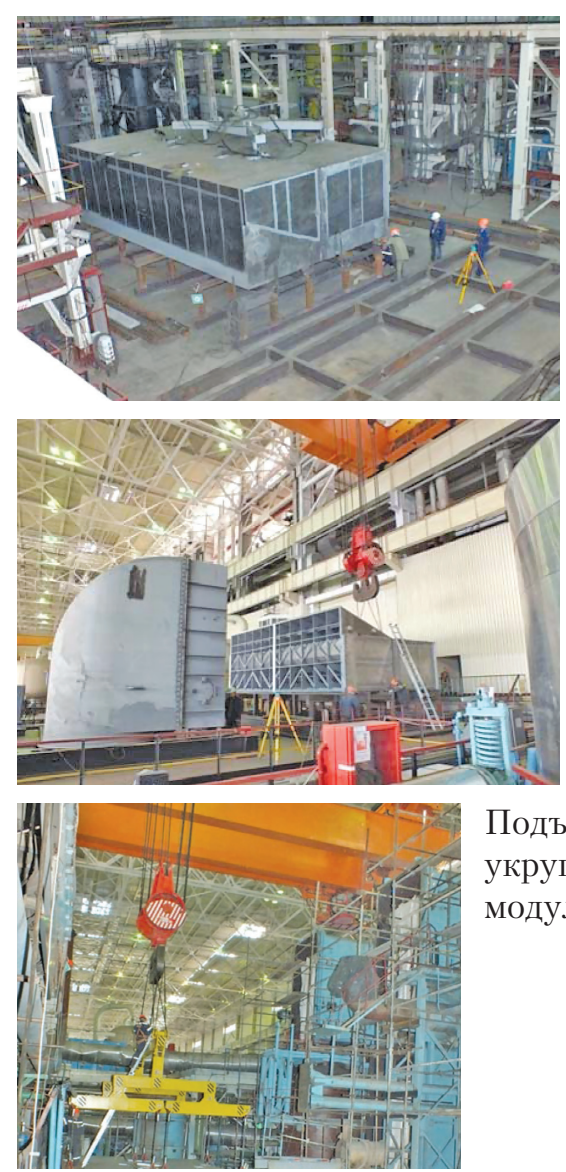

Разгрузка

укрупненных модулей

Сборка камеры и крышки и патрубка переходного
Подъём

укрупненных модулей

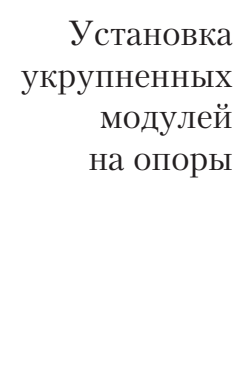

Установка модулей
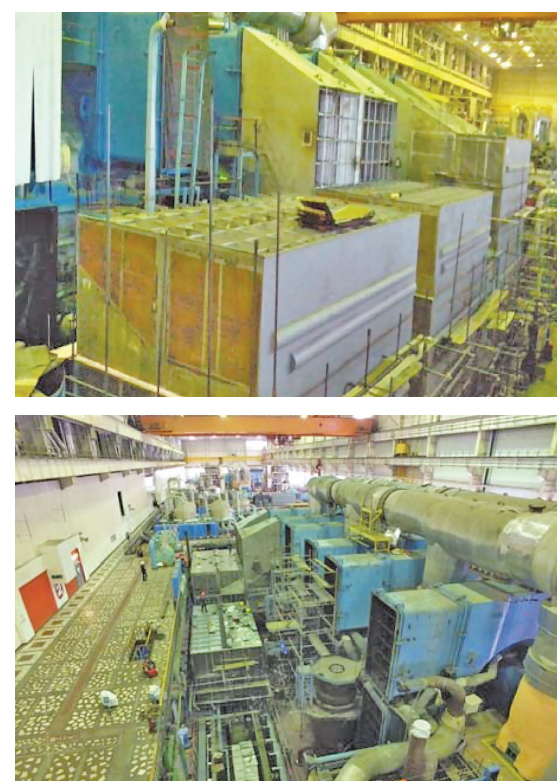

Окончательная сборка конденсатора

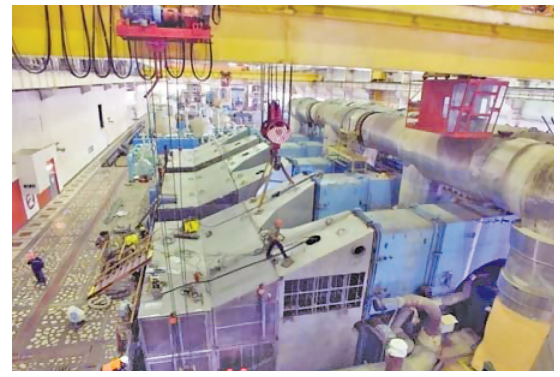

Рис. 15. Монтаж конденсатора К-57530 на ОП «Южно-Украинская АЭС», блок № 2 
Объём внедрения и эффективность

Системный подход при использовании научных достижений и новых разработок позволил добиться повышения экономичности турбоустановок АЭС за счет внедрения эффективных конденсаторов нового поколения, работающих в составе турбоустановок мощностью 1000 МВт. Эффективность новых конденсаторов подтверждена эксплуатацией их на энергоблоках мощностью 1000 МВт АЭС Украины. Фактический прирост электрической мощности на зажимах генератора с новыми конденсаторами «блочно-модульного» исполнения составил: 16,5...19,0 МВт на энергоблоке № 2 ОП «ЮжноУкраинская АЭС» турбоустановки К-1000-60/1500 (письмо ОП «Южно-Украинская АЭС», № 68-25/ 13120 от 03.07.2017 г., протокол № 32 от 01.06.2017 г.); 10,0 МВт на энергоблоке № 3 ОП «Запорожская АЭС» турбоустановки К-1000-60/1500-2 (ОП «Запорожская АЭС», Техническое решение № 03.TO.SD.TP. 86-18 от 26.01.2018 г.). Результаты по приросту электрической мощности турбоустановок на зажимах генератора не только покрывают расходы собственных нужд энергоблоков АЭС, но и экономят топливо на выработку одного кВтхчас, так как повышение электрической мощности ведет к снижению удельного расхода теплоты брутто/ нетто. Экономический эффект от внедрения конденсаторов нового поколения в «блочно-модульном» исполнении на ОП «Запорожская АЭС», блок № 3 - 1423000 тыс. грн. и на ОП «Южно-Украинская АЭС», блок № 2 - 1205140 тыс. грн.
Выводы

Созданные конструкции конденсаторов нового поколения «блочно-модульного» исполнения типа К-38080 и К-57530 для замены физически изношенных (существующих) конденсаторов турбоустановок мощностью 1000 МВт на действующих АЭС Украины являются своевременным шагом, необходимым для обеспечения энергобезопасности Украины и выполнения Энергетической стратегии страны на период до 2035 года. Технические решения при создании конденсаторов нового поколения в «блочно-модульном» исполнении, позволяют решить проблему обновления парка теплообменного оборудования на АЭС Украины на высоком техническом уровне с обеспечением требований по экономичности и надежности. Внедрение конденсаторов нового поколения «блочномодульного» исполнения обеспечивает надежную выработку электроэнергии с высокими техникоэкономическими показателями энергоблоков АЭС.

\section{Литература}

[1] Монография: Шавлаков О. В., Феофентов М. О., Панченко О. В., Касаткін О. Г., Усс О. М., Пацюк С. Т., Вавілов О. В., Харлампіді Д. Х. Розробка і впровадження конденсаторів парових турбін атомних електростанцій, - Харків: ФОП Панов А. М., 2018. - 248 с. (УДК 621.175.845.001.57).

[2] Паротурбинные установки атомных электростанций / П 18, Под редакцией Ю. Ф. Косяка. - М: 1978 г. 312 с., ил. (УДК 621.165:[621.311.25:621.039].

Shvetsov V.L.

TURBOATOM, JSC. Ukraine, Kharkov

\section{DEVELOPMENT AND IMPLEMENTATION OF CONDENSERS OF STEAM TURBINES FOR NUCLEAR POWER PLANTS}

Laying the scientific and technical groundwork for the development and implementation of highly efficient and reliable designs is aimed at creating new generation "block-modular" condensers equipped with tube systems made of corrosion-resistant material for $1000 \mathrm{MW}$ turbine plants with VVER-1000 reactors to replace worn-out and outdated designs of existing condensers that have exhausted their lifespan at nuclear power plants in Ukraine, and to be installed at NPP power units under new construction, in view of the increased reliability and operability, and extended service life of condensers. [dx.doi.org/10.29010/083.1]

Keywords: "block-modular" condenser; casing, water boxes; covers; hotwell; reducing pipe; cooling tubes; external tube sheets; intermediate tube sheets; turbine plant; blocks of modules; electric power gain. 